\title{
CORPORATE DEBT MATURITY AND ECONOMIC DEVELOPMENT
}

This paper analyses the effect of economic development on the influence of country-level determinants on corporate debt maturity. Corporate debt maturity increases with the efficiency of the legal system and bank concentration and decreases with the weight of banks in the economy. However, the importance of these country determinants is greater in developing than in developed countries. We also show that firm size in developed and developing countries influences country determinants of corporate debt maturity. Finally, our results reveal that the financial crisis has affected the debt maturity of firms differently in developed and developing countries, with the effect of bank concentration lengthening debt maturity, this effect being more pronounced in developing countries.

JEL classification: G18, G32.

Keywords: Economic development, corporate debt maturity; institutional environment; banking structure. 


\section{INTRODUCTION}

Papers analysing corporate debt maturity have revealed that debt maturity varies widely across countries $^{1}$. Consequently, Demirgüç-Kunt and Maksimovic (1999) and Fan et al. (2012) have examined how the differences in financial and legal institutions affect the choice of debt maturity by firms in an international context, considering that access to external financing will depend partly on the legal and institutional features of the country, as these provide the mechanisms for monitoring and enforcing financial contracts. Their papers highlight the importance of the efficiency of the legal system, corruption, the level of activity of the stock market and the size of the banking sector as determinants of debt maturity, as these country variables explain a significant portion of the variation in debt maturity ratios. However, these studies have not compared developed and developing economies in terms of the influence of country characteristics on corporate debt maturity.

In this context, the objective of this paper is to study how economic development influences the country determinants of debt maturity. This study contributes to the literature in a number of ways. First, we investigate the way in which observed differences in institutional quality and banking structure across developing and developed countries affect the corporate debt maturity choice. The influence of legal and institutional environments has also been analysed within a broad international context, as noted above, by Demirgüç-Kunt and Maksimovic (1999) and Fan et al. (2012). Empirical studies from the literature explaining corporate debt maturity have shown that agency costs and information asymmetries are important determinants of the choice of debt maturity (Barclay and Smith, 1995; Guedes and Opler, 1996, and Ozkan, 2000). The existence of greater informational asymmetries in developing countries may mean that

\footnotetext{
${ }^{1}$ For example, Antoniou et al. (2006) show that the maturity of debt -the long-term debt ratio- of French, German and UK listed firms is around 59\%, 53\% and 46\%, respectively. For a sample of US listed firms, Barclay and Smith (1995) report a percentage of total long-term debt of around 70\%. Deesomsak et al. (2009) show percentages of long-term debt of between $30 \%$ and $51.62 \%$ for their sample of listed firms in Thailand, Malaysia, Singapore and Australia.
} 
institutional and banking structure characteristics play a more important role in developing countries than in developed countries. Agca et al. (2007) provide evidence that reveals the different impact of financial reforms and financial openness in advanced and emerging economies on corporate debt maturity. These authors find that these transformations have lengthened debt maturity in advanced economies, but that corporate debt maturity in emerging countries has had a negative relationship with more international openness, while financial reforms have no effect on corporate debt maturity. Second, our paper also provides evidence regarding the effect of firm size on corporate debt maturity, analysing whether the effects for large and small firms are different in developed and developing countries. Finally, the financial crisis has opened up a debate about its consequences for firms, providing evidence that reveals the important effects of the financial crisis on the lending channel, supporting the existence of significant supply constraints in terms of both the quantity and price of credit leading to reductions in investment rates. In this context, we analyse how the financial crisis has affected the relationships between institutional quality and banking structure, economic development and corporate debt maturity.

The findings suggest that corporate debt maturity increases with legal enforcement and bank concentration and decreases with the weight of banks in the economy, regardless of the level of economic development of the country, although these country-specific determinants of debt maturity have greater influence in developing countries. The influence of the protection of creditors' rights on debt maturity is positive in developed countries and negative in developing countries, in line with the protection of creditors' rights affecting the incentives to monitor borrowers in developing countries. Firm size influences the country determinants of corporate debt maturity. Specifically, the weight of banks in the economy affects smaller firms more in developed and developing countries. Finally, the paper also provides evidence in line with the 
financial crisis affecting corporate debt maturity differently in developed and developing countries.

The rest of the paper is organised as follows. Section 2 provides a review of the literature and the hypotheses tested in the paper, while Section 3 presents the data, methodology and variables employed. Section 4 discusses the empirical results and, finally, Section 5 concludes the paper.

\section{LITERATURE REVIEW AND HYPOTHESES}

2.1. The influence of country-specific effects on corporate debt maturity

Demirgüç-Kunt and Maksimovic (1999) reveal that firms in developing countries use less longterm debt as a proportion of total debt and that this difference cannot be explained by the maturity of assets. Papers studying corporate debt maturity in an international context have consequently focused on the influence of country-specific effects (Fan et al, 2012; González, 2015; Hernández-Cánovas and Köeter-Kant, 2011; Kirch and Terra, 2012). Fan et al. (2012) examine how the institutional environment influences the capital structure and debt maturity choices of firms in 39 developed and developing countries. Their results show that the country's legal system, corruption and the preferences of capital suppliers explain a significant portion of debt maturity ratios. Hernández-Cánovas and Köeter-Kant (2011) examine the influence of cross-country differences on bank loan maturity for a sample of small and medium-sized enterprises (SMEs) from 19 European countries, finding that the protection of creditors' rights and legal enforcement benefit SMEs seeking long-term bank loans. Kirch and Terra (2012) analyse whether the financial development and institutional quality of a country has an effect on corporate debt maturity decisions for a sample of non-financial firms from five South American countries. Their results reveal that the institutional quality of a country has a significant positive effect on the level of long-term corporate debt, while the level of financial development does not influence debt maturity. Finally, González (2015) shows that corporate 
debt maturity was found to decline during the financial crisis for a sample of firms from 39 countries during the period 1995-2012, especially for those firms that were more dependent on external finance before the onset of the financial crisis. Summing up, these papers have revealed that legal enforcement, the protection of creditors' rights, the size of the banking sector and bank concentration are important determinants of corporate debt maturity. However, they do not consider whether the country-specific determinants are economic development dependent. Consequently, the main question addressed in this paper is how the economic development of the country influences the country determinants of debt maturity.

\subsection{Hypotheses}

Poor institutions and information disclosure characterize developing countries and may increase the intensity of information asymmetries (Levine et al., 2000; Claessens and Laeven, 2003). Information asymmetries are an important determinant of debt maturity (Barclay and Smith, 1995; Guedes and Opler, 1996; Ozkan, 2000) and may affect corporate debt maturity differently in developing countries. The presence of greater informational asymmetries in developing countries may mean that institutions and banking structure characteristics play a more important role in developing countries than in developed countries. In particular, bank concentration may be crucial in developing countries, as bank concentration favours state bank relationships and relationship banking may reduce the information asymmetries characteristic of developing countries. Thus, the hypotheses proposed in the paper are as follows:

H1. "The quality of institutions plays a more predominant role in developing than in developed economies".

H2. "Bank concentration will lengthen corporate debt maturity particularly in developing economies". 


\section{DATABASES, METHODOLOGY AND VARIABLES}

\subsection{Databases}

The influence of country characteristics on corporate debt maturity comparing developed and developing economies is analysed for a sample of listed firms, belonging to 39 countries, over the period 2005-2012. Our source for firm data is the Worldscope database, which contains financial statement data and stock prices from many countries in comparable form. Financial firms (SIC codes 6000 - 6999) were excluded from our sample, which finally comprises 30,727 firms and 171,892 firm-year observations. The sample includes countries with different institutional environments. To analyse whether country-level determinants of corporate debt maturity are similar in developed and developing countries, the overall sample is divided according to the country's economic development. To do so, we split our overall sample in developed and developing countries according to GNI per capita, calculated using the World Bank's Atlas method (Beck et al., 2009). Developed countries are those classified as high income and upper middle income, while low income and lower middle income countries are classified as developing economies. The sample includes 26 developed countries and 13 developing countries with 122,006 firm-year observations for developed countries and 49,886 firm-year observations for developing countries.

\subsection{Empirical model}

We estimate several versions of the following baseline regression model to investigate the influence of institutional and legal characteristics and banking structure on corporate debt maturity depending on the country's economic development: 


$$
\begin{aligned}
& D_{E B T M A T}=a_{0}+a_{1} A_{\text {SSET }} \text { MAT }_{i t-1}+a_{2} \text { GROWTH }_{i t-1}+a_{3} S I Z E_{i t-1}+ \\
& a_{4} \text { FIRM _ }_{-} \text {QUALITY }{ }_{i t-1}+a_{5} V O L_{-} E B I T_{i t-1}+a_{6} L E V_{i t-1}+b_{1} R U L E_{-} O F_{-} L A W_{k t} \\
& +b_{2} C_{-} \text {RIGHTS }_{k t}+b_{3} \text { BANK_CREDIT } T_{k t}+b_{4} B A N K_{-} \text {CONC }_{k t}+ \\
& \sum_{k t} \lambda_{k t}+\sum_{j t} \mu_{j t}+v_{i}+\varepsilon_{i t}
\end{aligned}
$$

We include three specific effects: country-year $\left(\sum_{k t} \lambda_{k t}\right)$, industry-year $\left(\sum_{j t} \mu_{j t}\right)$ and firmspecific $\left(v_{i}\right)$ effects. These specific effects aim to control for most shocks affecting debt maturity. This approach has the advantage of being less likely to suffer from omitted variable bias or model specification than traditional regressions (Dell'Ariccia et al., 2008). We use the Breusch-Pagan test (Breusch and Pagan, 1980) to identify the existence of individual effects. The null hypothesis of no unobserved heterogeneity is rejected in all the estimations. In this context, a model that captures individual heterogeneity, as the panel data methodology does, is appropriate. The panel data methodology corrects for unobserved firm-specific and timespecific effects. The panel data estimation was calculated using fixed effects, as the Hausman test (1978) rejects the null hypothesis of the lack of correlation between individual effects and observable variables in all regressions. All independent firm-level variables are lagged by one year to control for potential endogeneity problems.

\subsection{Variables}

The dependent variable is debt maturity (DEBTMAT), which is measured as the percentage of the firm's total debt with a maturity of more than one year ${ }^{2}$. To analyse the influence of economic development on corporate debt maturity, we control for the differences in the sample

\footnotetext{
2 This is the amount of long-term debt identified by standard accounting convention and traditionally used (Antoniou et al., 2006; Demirgüç-Kunt and Maksimovic, 1999; Fan et al., 2012; Kirch and Terra, 2012; and Scherr and Hulburt, 2001). Other authors have used alternative definitions. Barclay and Smith (1995) define debt maturity as long-term if it is payable after three years. Stohs and Mauer (1996) use a weighted average of the maturity of liabilities. Scherr and Hulburt (2001) also use the weighted average debt maturity. The papers using alternative measures have reported results that are not significantly different from those obtained when the standard definition is used. Our choice is also driven by data availability.
} 
in terms of firm and country characteristics. Corporate finance theory identifies asset maturity (ASSET_MAT), growth opportunities (GROWTH), size (SIZE), firm quality (FIRM_QUALITY), volatility of earnings (VOL_EBIT) and leverage (LEV) as key determinants of corporate debt maturity (Myers, 1977; Barnea et al., 1980; Barclay and Smith, 1995; Stohs and Mauer, 1996; Guedes and Opler, 1996; Antoniou et al., 2006). We thus control for the differences in firm characteristics in the sample among countries by introducing the following firm-level variables.

The underinvestment problem due to agency conflicts between shareholders and creditors can be reduced by matching the maturity of a firm's debt to that of its assets (Myers, 1977). Thus, the relationship between debt maturity and debt assets should be positive. As a measure of the maturity of assets, we have considered the ratio between net fixed assets and total assets (ASSET_MAT).

When a firm has future growth opportunities, shareholders have incentives to undertake such projects, as the benefits are shared with debtholders. A firm may control this underinvestment incentive by reducing the amount of debt in the firm's capital structure, by including restrictive covenants in debt contracts, or by shortening the maturity of the firm's debt. We have measured the firm's investment opportunities set by the market-to-book ratio (GROWTH).

Agency problems between shareholders and debtholders may be particularly severe for small firms as a consequence of underinvestment incentives and risk shifting. Barnea et al. (1980) suggest that these problems may be reduced by issuing shorter-term debt. These arguments thus suggest that debt maturity varies directly with firm size. We have measured firm size as the natural logarithm of sales (SIZE).

The liquidity risk argument holds that the incentives to lengthen the maturity of debt increase with the risk of not being able to refund debt. In this context, high-quality firms will prefer to 
issue short-term debt. Following Antoniou et al. (2006), we use the ratio of net income plus depreciation to net debt as a proxy for firm quality (FIRM_QUALITY).

Firms whose value is highly volatile have to change their capital structure frequently to reduce bankruptcy costs and hence these firms will use more short-term debt (Kane et al., 1985). In this context, the maturity of debt should increase if the volatility of firm value decreases. The firm's level of volatility is measured as the absolute value of change in earnings before interest and taxes (VOL_EBIT).

Diamond (1991) shows that liquidity risk increases with leverage and hence that highly leveraged firms should use more long-term debt. However, Barclay et al. (2003) argue that leverage and maturity are substitute mechanisms in mitigating under- and overinvestment problems and that the relationship between them should be negative. Leverage has been measured as the ratio between total debt and firm market value (LEV), the market value of assets being defined as total assets minus the book value of equity plus the market value of equity.

Following the paper by Fan et al. (2012), our estimations control for country determinants of debt maturity. These variables are rule of law, protection of creditors' rights, the weight of banks in the economy and bank concentration. We have used the rule of law component from the Worldwide Governance Indicators (WGI) compiled by Kaufmann et al. (2009) to proxy the efficiency of a country's legal system (RULE_OF_LAW). This index ranges from -2.5 to 2.5 , lower levels of the index denoting less efficiency in the legal system. To measure the legal rights of creditors against defaulting debtors (C_RIGHTS), we consider the index developed in Djankov et al. (2007) which follows the creditors' rights index proposed by La Porta et al. (1998). It combines four dimensions of creditor rights: (1) restrictions on reorganisation, (2) the existence of automatic stay or asset freeze, (3) priority of payment for secured creditors, 
and (4) management of the firm during reorganisation. A value of one is added to the index when a country's laws and regulations provide each one of these powers to secured lenders. The creditors' rights index thus varies between 0 and 4, with higher values indicating stronger creditors' rights or stronger protection against borrower expropriation.

We also use two variables to proxy the banking structure in the country. First, the weight of banks in the economy, measured as the ratio of private credit by deposit money banks to GDP (BANK_CREDIT). The data are obtained from the Financial Structure and Economic Database (Beck et al., 2009). Second, we use a measure of bank concentration in a country. Following Demirgüç-Kunt et al. (2004) and Beck et al. (2006), we measure bank concentration as the fraction of bank assets held by the three largest commercial banks in the country (BANK_CONC). Figures are obtained from the World Bank Database, whose main source is Fitch IBCA’s Bankscope Database.

\subsection{Descriptive statistics}

Table 1 provides descriptive statistics on the firm- and country-level variables used in this paper. Panel A describes all the firms included in the sample, while Panels B and C show the descriptive statistics per country according to its economic development. The mean (median) debt maturity of the sample is 47.19 (48.19) per cent. Firms in developed countries present higher average maturity of debt (49.42 per cent) than firms in developing countries (41.72 per cent). Firms in developed countries are less leveraged, are larger, have more growth opportunities and have less asset maturity than those in developing countries. As for the institutional and banking structure variables, developed countries present higher rule of law, bank concentration and weight of banks in the economy, while the protection of creditors' 
rights is higher in developing countries ${ }^{3}$. Ratios of debt maturity vary widely among countries. On the one hand, Thailand, South Korea, Turkey, Malaysia and Pakistan, all of which are developing countries, have the lowest ratio of long-term debt over total debt. In contrast, the US has the highest percentage of long-term debt (73.10 per cent). Table 2 shows the correlation matrix. DEBT_MAT shows a positive correlation with asset maturity, growth opportunities, size, leverage and rule of law, but correlates negatively with firm quality, volatility of earnings, protection of creditors' rights, bank financing and bank concentration. In line with the longer debt maturity of firms in developed countries, the correlation between debt maturity and economic development is positive. In general, the correlations among firm-level variables are low and the correlations among country-level variables do not affect the results as the coefficients are similar when each country variable is considered individually.

\section{INSERT TABLES 1 AND 2 ABOUT HERE}

\section{EMPIRICAL ANALYSIS}

Table 3 presents the results of the model estimations [1] for the overall sample and the subsamples of developed and developing countries. Columns (1) and (2) provide the results for the overall sample, while columns (3) and (4) and (5) and (6) show the results for developing and developed countries, respectively. For each sample or subsample, the first column considers only firm-level determinants of debt maturity, while the second includes both firmand country-level determinants of debt maturity.

As regards firm determinants, the results in column (1) reveal that corporate debt maturity has a positive relationship with asset maturity, growth opportunities, size and leverage, while the

\footnotetext{
${ }^{3}$ La Porta et al. (1998) show that creditors' rights are stronger in poorer than in richer countries and that this might be due to poor countries adapting their laws to promote lending as a consequence of the lack of other financing opportunities.
} 
relationship with firm quality is negative. The relationship between debt maturity and asset maturity is positive, as firms attempt to match the maturities of assets and liabilities in order to reduce risks. Debt maturity also increases with firm size, confirming the hypothesis that agency costs of debt may be higher for small firms as a consequence of underinvestment incentives and risk shifting. In this context, small firms tend to shorten their debt maturity to reduce agency costs of debt. This positive relationship between debt maturity and size also provides support for the signalling explanation, as small firms have higher levels of asymmetric information. Debt maturity has a negative relationship with firm quality, providing support for the liquidity risk argument, in which low quality firms prefer to issue long-term debt to reduce the risk of not being able to refund debt. Debt maturity is positively related to leverage, as the risk of liquidity increases with leverage (Diamond, 1991). High leverage thus encourages firms to use more long-term debt. Finally, debt maturity has a positive relationship with firm growth opportunities. This relationship is not in line with agency costs arguments. Myers (1977) states that firms may reduce underinvestment incentives by shortening the maturity of debt. From this point of view, the relationship between growth opportunities and debt should be negative. However, a positive relationship between the market-to-book ratio and debt maturity has been also reported by Fan et al. (2012) and Stohs and Mauer (1996). Longer debt maturity with growth opportunities could be due to firms with higher investment opportunities preferring to hedge against liquidity risk by issuing longer-term debt.

These findings for firm characteristics are broadly consistent with the theoretical and empirical literature on corporate debt maturity. The results provide strong evidence in line with the matching and liquidity risk arguments and only partial evidence supporting the agency cost argument. 
The findings for country-level determinants show that corporate debt maturity lengthens with the efficiency of the legal system, the protection of creditors' rights and bank concentration, while it shortens with the weight of banks in the economy. The positive and significant effect of rule of law on debt maturity is consistent with Demirgüç-Kunt and Maksimovic (1999) and means that the higher the quality of legal institutions, the greater the proportion of long-term financing. Thus, firms use more short-term debt in countries in which the legal system does not provide proper protection or is costly to use. The level of protection of creditors' rights (C_RIGHTS) has a positive influence on debt maturity. This result suggests that creditors are willing to lend on more favourable terms -longer maturities- when their rights are strongly protected, as this reduces creditors' risk and increases borrowers' incentives to repay loans and avoid bankruptcy. This positive relationship between debt maturity and protection of creditors' rights is consistent with the evidence provided by Qian and Strahan (2007) for bank loans. As for bank concentration, the maturity of debt increases in countries in which bank concentration is high. This result suggests that higher bank concentration increases bank incentives to establish close relationships with borrowers over time and thus reduces the financial constraints on firms. This finding is also consistent with Hernández-Cánovas and Koëter-Kant (2008), who show that stronger firm-bank relationships lengthen the maturity of banks loans for a sample of SMEs from 19 European countries. Finally, the weight of banks is seen to have a negative influence on debt maturity. This result is in line with the evidence provided by Fan et al. (2012), which is consistent with the preferences of suppliers of capital having an influence on debt maturity structures.

\subsection{Economic development and firm- and country-specific effects on debt maturity}

The main contribution of this paper is that of analysing the main similarities and differences in the determinants of corporate debt maturity between developed and developing economies. 
When considering the subsamples of developing and developed countries separately, we find important similarities as well as differences between corporate financing behaviour in the two types of economies. The coefficients of asset maturity, growth opportunities, earnings volatility, firm quality and leverage have the same sign, although there are some differences in their values. The coefficients for ASSET_MAT and GROWTH are higher for firms in developing countries, while leverage has a lower coefficient in developing than in developed countries. These differences suggest that the determinants of debt maturity in developing countries are consistent with the matching and liquidity risk arguments to a greater extent. There is only one difference in sign when considering the firm-level determinants of corporate debt maturity: firm size is found shorten debt maturity in developing countries. This result may be related to the lack of developed bonds markets in these countries.

\section{INSERT TABLE 3 ABOUT HERE}

As for country determinants of firms' debt maturity, the results reveal that the effect of RULE_LAW, BANK_CONC and BANK_CREDIT is greater in developing countries. The debt maturity of firms in developing countries is thus more dependent on the efficiency of the legal system, bank concentration and the weight of banks in the economy than in developed countries. However, the most important difference with respect to the results shown in column

(2) is that corporate debt maturity in developing countries decreases with the protection of creditors' rights. Creditors' rights may influence corporate debt maturity in several ways. First, when the rights of creditors are better protected, these will be more likely to force repayment, take collateral and gain control of firms in the case of bankruptcy. This increases the recovery rate of loans for creditors and hence reduces their risk and will exert an ex ante influence on the terms of the credit. Second, stronger protection of creditors' rights may reduce the incentives for borrowers to engage in excessive risk taking and assets substitution, as they 
suffer higher costs following bankruptcy, thereby reducing moral hazard problems. According to these arguments, lenders will lend on more favourable terms (e.g. longer maturities) when creditors' rights are better protected, which is consistent with the evidence provided by Qian and Strahan (2007). However, protection of creditors' rights may also influence the incentives of lenders to monitor borrowers, as it increases the recovery rate of loans when the firm fails. Due to the fact that the protection of creditors' rights decreases the incentives to monitor borrowers, it could lead lenders/banks to use other mechanisms to reduce this risk. It may be also affected by the weaker legal enforcement in developing countries. One of these mechanisms could be the use of short-term debt. The negative relationship between corporate debt maturity and protection of creditors' rights in developing countries is consistent with stronger protection of creditors' rights negatively affecting the incentives for creditors to monitor borrowers.

The results for developed countries show that the efficiency of the legal system has a positive influence on corporate debt maturity, although this influence is not statistically significant at standard levels. Bank concentration in developed countries shortens corporate debt maturity. This finding reveals the different role that relationship banking has in developed and developing countries. It is consistent with a higher value of relationship banking in developing countries resulting from the reduction in asymmetric information problems, which are more pronounced in less developed countries (Levine et al., 2000; Claessens and Laeven, 2003). In developing countries, bank concentration constitutes a useful mechanism to reduce information asymmetries, replacing the role of institutions. In addition, the reduction of debt maturity in developed countries where banks have a large weight in firms' financing is lower compared to developing countries. This result may be a consequence of the existence of more financing alternatives for firms in developed countries. Firms in developed countries have better access to domestic and international markets and are therefore less dependent on the preferences of 
domestic banks. In general, these results show that corporate debt maturity depends on country characteristics more in developing countries than in developed countries. In line with hypothesis $\mathrm{H} 1$, the quality of institutions, measured by the efficiency of the legal system (RULE_LAW), has a more positive influence on corporate debt maturity in developing economies. Furthermore, the existence of a positive coefficient of BANK_CONC in developing economies and a negative coefficient in developed countries is consistent with bank concentration lengthening corporate debt maturity only in developing economies, offering support to hypothesis $\mathrm{H} 2$.

\subsection{Economic development, firm size and debt maturity}

Firm size influences corporate debt maturity (Demirgüç-Kunt and Maksimovic, 1999). We accordingly analyse whether the country effects on debt maturity are the same between large and small firms in developed and developing countries. To do so, the overall sample is divided into quartiles according to total assets and the variables LARGE and SMALL are created. LARGE is a dummy variable that takes the value of 1 if the firm belongs to the largest quartile and 0 otherwise. SMALL is a dummy variable that takes the value of 1 if the firm belongs to the smallest quartile and 0 otherwise. To analyse the influence of firm size on country-level determinants in developed and developing countries, these two variables are multiplied by each one of these determinants. Columns (1) and (2) in Table 4 show the results for developing countries, while columns (3) and (4) provide the results for developed countries. In column (1), the coefficients of country characteristics, namely RULE_OF_LAW, C_RIGHTS, BANK_CONC and BANK_CREDIT, show the effect of country-level determinants of debt maturity in developing countries for small-sized firms, while the interaction terms LARGE*RULE_OF_LAW, LARGE*C_RIGHTS, LARGE*BANKS_CONC and 
LARGE*BANK_CREDIT capture the differential effect of the country-level determinants of debt maturity for large firms in developing countries.

The results in columns (1) and (2) show that the influences of firm characteristics on corporate debt maturity in developing countries are the same as those explained previously in columns (3) and (4) in Table 3. As for the effect of country characteristics in developing countries, the results reveal that corporate debt maturity increases with the efficiency of the legal system and bank concentration, and decreases with protection of creditors' rights and the weight of banks. These effects are similar to those for developing countries shown in column (4) in Table 3. The interaction of the LARGE variable with country determinants of debt maturity shows that larger firms suffer less reduction in debt maturity in developing countries in which banks play a major role in the economy. Conversely, smaller firms in developing countries experience greater decreases when banks play an important role in the financing of the private sector. This result is consistent with the preferences of suppliers of debt financing having a greater effect on smaller firms, as these are more dependent on bank financing. Large firms have better access to domestic and international markets and hence are less dependent on bank financing. Furthermore, the efficiency of the legal system benefits smaller firms more than larger firms in developing countries, allowing them to increase debt maturity. Protection of creditors' rights and bank concentration do not show a differential effect for larger or smaller firms in developing countries.

\section{INSERT TABLE 4 ABOUT HERE}

Columns (3) and (4) present the results when developed countries are considered. As regards the effect of firm characteristics, we do not observe any differences with respect to the results in Table 3. As to the country determinants, corporate debt maturity in developed countries presents a positive relationship with the efficiency of the legal system and the protection of 
creditors' rights, and a negative relationship with bank concentration and the weight of banks. However, the relationship of debt maturity with the efficiency of the legal system is not statistically significant, while its relationship with bank concentration is only marginally statistically significant. The interaction of the variable LARGE with the country determinants of debt maturity shows that larger firms also suffer a lower reduction in debt maturity in developed countries in which banks play a major role in the economy. Conversely, smaller firms in developed countries are the ones that experience greater decreases when banks play an important role in the financing of the private sector. The positive coefficient of C_RIGHTS in column (3) and the negative coefficient of LARGE*C_RIGHTS suggest that the protection of creditors' rights increases the debt maturity of large firms less in developed countries. The results in column (4) show that the same may be said of smaller firms. Both findings suggest that medium-sized firms are the ones to benefit more from a high level of protection of creditors' rights in developed countries.

Summing up, these results reveal that the country-level determinants of corporate debt maturity introduce differences between large and small firms in developing and developed countries. The main similarity between firms in developed and developing countries according to their size is that small firms suffer greater decreases in debt maturity when banks have a large weight in the financing of the private sector. This is a consequence of small firms having more financing constraints. Despite this similar effect of the role of banks, the reduction in debt maturity in countries where banks play a major role in the economy is much higher in developing countries. This finding is in line with banks imposing more credit restrictions (e.g. lower maturities) in developing countries, as firms have less alternative sources of financing available to them.

4.3. Economic development, the financial crisis and debt maturity 
A growing number of empirical papers have studied the consequences of the financial crisis on the lending channel. Ivashina and Scharfstein (2010) show that syndicated lending started to decline in mid-2007 and fell sharply during the bank panic that began in September 2008 for US firms. The bank lending survey by the European Central Bank (ECB) shows that the financial crisis also reduced the credit issued by banks in European countries ${ }^{4}$. Santos (2011) shows that firms paid higher loan spreads during the subprime crisis and that the increase in loan spreads was higher for firms which borrowed from banks that incurred greater losses. González (2015) shows that corporate debt maturity was found to decline during the financial crisis. We accordingly analyse whether the effects of the crisis and the influence of country effects on corporate debt maturity are the same during the period of the financial crisis in developed and developing countries.

Table 5 shows the results when we consider the influence that the financial crisis has had on the effect of country-specific effects on debt maturity according to the economic development of the country. We introduce the variable DCRISIS in the estimations, as well as the interactions of this variable with RULE_OF_LAW, C_RIGHTS, BANK_CONC and BANK_CREDIT. DCRISIS is a dummy variable that takes the value of 1 for the period from 2008 to 2012 and 0 otherwise. The country-level variables in column (1) accordingly show the effect of these characteristics on debt maturity before the financial crisis for the overall sample, while columns (2) and (3) respectively present the results for developing and developed countries before the financial crisis. The interaction terms between DCRISIS and the countryspecific variables capture the differential effect of these variables on debt maturity during the financial crisis.

\footnotetext{
${ }^{4}$ This survey is addressed to senior loan officers of a representative sample of euro area banks and is conducted four times a year. Detailed information on the survey and results are available at https://www.ecb.europa.eu/stats/money/surveys/lend/html/index.en.html.
} 


\section{INSERT TABLE 5 ABOUT HERE}

The results show that the financial crisis reduces corporate debt maturity for the overall sample. This finding is in line with the existence of stronger tightening in credit standards by lenders during the financial crisis (González, 2015). As for the firm-specific effects on debt maturity, the results are similar to those explained in Table 3. As regards country-specific effects before the crisis, corporate debt maturity in the overall sample increases with the efficiency of the legal system, the protection of creditors' rights and bank concentration, and decreases with the weight of banks in the economy. We observe two differences for the financial crisis period. These differences are the positive differential effects of the efficiency of the legal system and bank concentration. During the financial crisis, firms have more facilities to lengthen their debt maturity in countries with strong legal enforcement and a high level of bank concentration. This result reveals that during the period of crisis the quality of institutions and relationship banking, favoured by bank concentration, have provided benefits for firms from longer debt maturities.

The results during the crisis period are partly similar when we divide the sample into developed and developing countries. Corporate debt maturity also increases during the financial crisis in developing countries with a highly efficient legal system and a high level of bank concentration, although the effect for the legal system is not statistically significant at standard levels. For developed countries, the efficiency of the legal system and bank concentration also increase corporate debt maturity during the crisis. Legal enforcement and bank concentration have no effect on corporate debt maturity before the financial crisis in developed countries, but these characteristics become relevant during the crisis, increasing corporate debt maturity.

Corporate debt maturity in developed countries decreases during the financial crisis when banks play a major role in the economy. Moreover, the financial crisis reduces corporate debt 
maturity for firms in developed countries, while the effect is not significant for firms located in developing countries. This last result is consistent with the consequences of financial crisis being less important in developing economies.

These results reveal that firms benefit from larger debt maturities during the crisis in countries with a high quality legal system. The positive effect of bank concentration suggests the importance of relationship banking during the period of crisis as a mechanism for reducing asymmetric information problems and solving the problem of tightening in credit standards by lenders.

\section{CONCLUSIONS}

This paper analyses the importance of economic development in country-specific effects on corporate debt maturity. In line with previous evidence, corporate debt maturity increases with the efficiency of the legal system and bank concentration, and decreases with the weight of banks in the economy. However, country-specific effects affect firms differently depending on the country's economic development, the effects being more important in developing countries. In terms of the lengthening of debt maturity, firms in developing countries benefit more from increases in rule of law and bank concentration. However, corporate debt maturity in developing countries decreases with the weight of banks in corporate financing.

Furthermore, the role of creditors' rights highlights the predominance of the reduction in risk for creditors and moral hazard problems as a consequence of increase in the protection of creditors' rights in developed countries, while the decrease in incentives for lenders to monitor borrowers when the protection of creditors' rights increases has a greater effect in developing countries. 
The results also reveal that country-specific effects on corporate debt maturity are size dependent, as some country characteristics affect large and small firms differently in developed and developing countries. First, the findings show that smaller firms in developed and developing countries experience sharp reductions in debt maturity when banks play an important role in the economy. Second, the efficiency of the legal system benefits smaller firms more than larger firms in developing countries.

Finally, the paper also provides evidence in line with a positive influence of bank concentration on debt maturity during the financial crisis, regardless of the country's level of economic development, although this effect is more pronounced in developing countries. Rule of law also increases debt maturity during the financial crisis in developed countries, while there is no effect before the crisis. In the case of developing countries, however, rule of law has a positive effect on corporate debt maturity regardless of the existence of a financial crisis.

Summing up, our findings reveal that the adequacy of policies to provide access to long-term financing depends on the economic development, firm size and the financial crisis. The economic development of the country mainly influences the effect of country-level determinants of debt maturity. Moreover, we provide evidence suggesting that firm size and the financial crisis impose differences between developed and developing economies. 


\section{REFERENCES}

Agca, S.; De Nicolo, G., and Detragiache, E., 2007. Financial reforms, financial openness, and corporate borrowing: International evidence. IMF Working Paper 07/186.

Antoniou, A., Guney, Y., and Paudyal, K., 2006. The determinants of debt maturity structure: evidence from France, Germany and the UK. European Financial Management, 12 (2), 161-194.

Barclay, M.J., and Smith, C.W., 1995. The maturity structure of corporate debt. Journal of Finance 50, 609-631.

Barnea, A., Haugen, R.A. and Senbet, L.W., 1980. A rationale for debt maturity structure and call provisions in the agency theoretic framework. The Journal of Finance, 35 (5), 1223-1234.

Beck, T., Demirgüç-Kunt, A., and Levine, R., 2006. Bank concentration, competition, and crises: first results. Journal of Banking and Finance 30, 1581-1603.

Beck, T., Demirgüç-Kunt, A., and Levine, R., 2009. Financial Institutions and Markets Across Countries and over Time: Data and Analysis. World Bank Policy Research Working Paper 4943. Database available at http://econ.worldbank.org.

Breusch, T. S. and Pagan, A. R., 1980. The Lagrange Multiplier Test and its Applications to Model Specification in Econometrics. Review of Economic Studies 47 (1), 239-253.

Claessens, S., \& Laeven, L., 2003. Financial development, property rights, and growth. Journal of Finance, 58, 2401-2436.

Deesomsak, R., Paudyal, K, and Pescetto, G., 2009. Debt maturity structure and the 1997 Asian financial crisis. Journal of Multinational Financial Management 19, 26-42.

Dell'Ariccia, G., Detragiache, E., and Rajan. R., 2008. The Real Effect of Banking Crises. Journal of Financial Intermediation 17, 89-112.

Demirgüç-Kunt, A., Laeven, L., and Levine, R., 2004. Regulations, market structure, institutions, and the cost of financial intermediation. Journal of Money, Credit, and Banking 36, 593-622.

Demirgüç-Kunt, A., Maksimovic, V., 1999. Institutions, financial markets, and firm debt maturity. Journal of Financial Economics 54, 295-336.

Diamond, D.W., 1991. Debt maturity and liquidity risk. Quarterly Journal of Economics 106, 709-737.

Djankov, S., McLiesh, C., and Shleifer, A., 2007. Private credit in 129 countries. Journal of Financial Economics 84, 299-329.

Fan, J.P.H., Titman, S., and Twite, G., 2012. An International Comparison of Capital Structure and Debt Maturity Choices. Journal of Financial and Quantitative Analysis 47 (1), 23 56.

González, V.M., 2015. The financial crisis and corporate debt maturity: The role of banking structure. Journal of Corporate Finance 35, 310-328.

Guedes, J. and Opler, T., 1996. The determinants of the maturity of corporate debt issues. The Journal of Finance, 51 (1), 1809-1833.

Hausman, J. A., 1978. Specification tests in econometrics. Econometrica 46 (6), 1251-1271. 
Hernández-Cánovas, G. and Koëter-Kant, J., 2008. Debt maturity and relationship lending. An analysis of European SMEs. International Small Business Journal, 26 (5), 595-617.

Hernández-Cánovas, G. and Koëter-Kant, J., 2011. SME financing in Europe: Cross-country determinants of bank loan maturity. International Small Business Journal, 29 (5), 489507.

Ivashina, V., Scharfstein, D., 2010. Bank lending during the financial crisis of 2008. Journal of Financial Economics 97, 319-338.

Kane, A., Marcus, A.J. and McDonald, R.L., 1985. Debt policy and the rate of return premium to leverage. Journal of Financial and Quantitative Analysis, 20, 479-499.

Kaufmann, D., Kraay, A., and Mastruzzi, M., 2009. Governance Matters VIII: Aggregate and Individual Governance Indicators, 1996-2008. World Bank Policy Research Working Paper No. 4978.

Kirch, G. and Terra, P.R.S., 2012. Determinants of corporate debt maturity in South America: Do institutional quality and financial development matter? Journal of Corporate Finance 18, 980-993.

La Porta, R., Lopez-de-Silanes, F., Shleifer, A., and Vishny, R.W., 1998. Law and finance. Journal of Political Economy 106, 1113-1155.

Levine, R., Loayza, N., \& Beck, T., 2000. Financial intermediation and growth: Causality and causes. Journal of Monetary Economics, 46, 31-77.

Myers, S.C., 1977. Determinants of corporate borrowing. Journal of Financial Economics, 5 (2), 147-175.

Ozkan, A., 2000. Determinants of capital structure and adjustment to long run target: Evidence from UK company panel data. Journal of Business, Finance \& Accounting, 28 (1), 175 198.

Qian, J., and Strahan, P.E., 2007. How law and institutions shape financial contracts: The case of bank loans. Journal of Finance 62, 2803-2834.

Santos, J.A.C., 2011. Bank corporate loan pricing following the subprime crisis. Review of Financial Studies 24 (6), 1916-1943.

Scherr, F.C. and Hulburt, H.M., 2001. The debt maturity structure of small firms. Financial Management, 30 (1), 85-111.

Stohs, M.H. and Mauer, D.C., 1996. The determinants of corporate debt maturity structure. Journal of Business, 69, 279-312. 
Table 1. Descriptive statistics by country

This table reports the descriptive statistics of firm- and country-level variables for the total sample (Panel A) and for each country divided into developed (Panel B) and developing countries (Panel C). Developed countries are those classified as high income and upper middle income, while developing countries are those classified as low income and lower middle income according to GNI per capita, calculated using the World Bank's Atlas method (Beck et al., 2009). DEBT_MAT is the percentage of the firm's total debt with a maturity of more than one year. ASSET_MAT is the ratio between net fixed assets and total assets. GROWTH is the market-to-book ratio. SIZE is the natural logarithm of sales. VOL EBIT is the absolute value of change in earnings before interest and taxes. FIRM_QUALITY is the ratio of net income plus depreciation to net debt. LEV is the ratio between total debt and the firm's before interest and taxes. FIRM_QUALITY is the ratio of net income plus depreciation to net debt. LEV is the ratio between total debt and the firm's
market value. RULE OF LAW is one of the six dimensions of the Worldwide Governance Indicators compiled by Kaufmann et al. (2009) and is a measure market value. RULE OF LAW is one of the six dimensions of the Worldwide Governance Indicators compiled by Kaufmann et al. (2009) and is a measure
of the efficiency of the legal system. C_RIGHTS measures the protection of creditor rights. BANK_CONC is the fraction of assets held by the three largest commercial banks in each country. BANK_CREDIT is the ratio of private credit by deposit money banks to GDP.

\begin{tabular}{|c|c|c|c|c|c|c|c|c|c|c|c|}
\hline & & \multicolumn{2}{|c|}{ Mean } & Median & \multicolumn{3}{|c|}{ Standard Deviation } & \multicolumn{2}{|c|}{ First quartile } & \multicolumn{2}{|c|}{ Third quartile } \\
\hline \multicolumn{12}{|c|}{ PANEL A: TOTAL SAMPLE } \\
\hline \multicolumn{2}{|c|}{ DEBT_MAT (\%) } & \multicolumn{2}{|c|}{47.19} & 48.19 & \multicolumn{3}{|c|}{34.01} & \multicolumn{2}{|c|}{14.23} & \multicolumn{2}{|c|}{77.35} \\
\hline ASSET_MAT & & & & 30.36 & & 22.19 & & & & & \\
\hline GROWTH & & & & 1.21 & & 2.02 & & & & & \\
\hline SIZE & & & & 5.15 & & 2.09 & & & & & \\
\hline VOL_EBIT & & & & 0.48 & & 2.77 & & & & & \\
\hline FIRM_QUAL & & & & 0.38 & & 10.56 & & & & & \\
\hline LEV (\%) & & & & 28.31 & & 25.03 & & & & & \\
\hline RULE_OF_L & & & & 1.32 & & 0.70 & & & & & \\
\hline S_RIGHTS & & & & 70.00 & & 16.89 & & & 00 & & \\
\hline C_RIGHTS & & & & 2.00 & & 1.09 & & & 00 & & \\
\hline BANK_CON & (\%) & & & 46.75 & & 19.44 & & & 12 & & \\
\hline BANK CRED & Г $(\%)$ & & & 98.43 & & 40.01 & & & & & \\
\hline & $\begin{array}{c}\text { DEBT_MAT } \\
(\%)\end{array}$ & $\begin{array}{c}\text { ASSET_MAT } \\
(\%)\end{array}$ & GROWTH & SIZE & VOL_EBIT & $\begin{array}{c}\text { FIRM } \\
\text { QUALITY }\end{array}$ & LEV & $\begin{array}{c}\text { RULE } \\
\text { OF } \\
\text { LAW } \\
\end{array}$ & C_RIGHTS & $\begin{array}{c}\text { BANK } \\
\text { CONC } \\
(\%) \\
\end{array}$ & $\begin{array}{c}\text { BANK } \\
\text { CREDIT } \\
(\%) \\
\end{array}$ \\
\hline PANEL B: DE & JELOPED COU & NTRIES & & & & & & & & & \\
\hline Argentina & 45.16 & 46.76 & 1.22 & 5.00 & 1.29 & 3.23 & 33.35 & -0.56 & 1.00 & 40.41 & 13.95 \\
\hline Australia & 49.76 & 32.79 & 2.14 & 3.99 & 1.59 & 2.05 & 25.64 & 1.76 & 3.00 & 65.45 & 108.99 \\
\hline Austria & 50.71 & 35.46 & 1.61 & 5.88 & 1.07 & 1.40 & 35.25 & 1.85 & 3.00 & 64.64 & 110.46 \\
\hline Belgium & 50.51 & 29.99 & 2.13 & 5.48 & 1.26 & 2.12 & 32.04 & 1.39 & 2.00 & 87.13 & 82.86 \\
\hline Canada & 59.88 & 45.65 & 2.06 & 4.46 & 1.76 & 1.21 & 28.13 & 1.77 & 1.00 & 60.20 & 95.61 \\
\hline Denmark & 52.29 & 33.86 & 2.08 & 5.00 & 1.28 & 1.20 & 29.73 & 1.90 & 3.00 & 79.77 & 124.06 \\
\hline Finland & 58.72 & 27.78 & 2.08 & 5.67 & 1.13 & 1.91 & 28.26 & 1.93 & 1.00 & 96.35 & 74.81 \\
\hline France & 50.72 & 18.81 & 2.20 & 5.39 & 1.28 & 2.23 & 29.09 & 1.42 & 0.00 & 60.26 & 98.73 \\
\hline Germany & 51.37 & 26.49 & 2.16 & 5.48 & 1.39 & 2.73 & 30.82 & 1.68 & 3.00 & 69.56 & 110.50 \\
\hline Greece & 36.07 & 37.79 & 1.90 & 4.40 & 1.10 & 1.15 & 42.15 & 0.72 & 1.00 & 67.97 & 78.76 \\
\hline Hong Kong & 37.65 & 27.51 & 1.54 & 4.64 & 1.59 & 1.78 & 30.36 & 1.43 & 4.00 & 70.17 & 152.38 \\
\hline Ireland & 63.48 & 29.02 & 2.65 & 6.01 & 0.98 & 2.36 & 27.70 & 1.68 & 1.00 & 66.63 & 152.15 \\
\hline Israel & 50.72 & 24.04 & 1.76 & 4.60 & 1.37 & 1.21 & 41.60 & 0.89 & 3.00 & 78.15 & 90.92 \\
\hline Italy & 45.76 & 23.52 & 1.91 & 5.93 & 1.26 & 1.10 & 37.11 & 0.53 & 2.00 & 46.88 & 93.44 \\
\hline Japan & 40.03 & 31.35 & 1.30 & 6.22 & 1.21 & 2.17 & 36.65 & 1.33 & 1.20 & 41.46 & 104.79 \\
\hline Netherlands & 56.71 & 25.27 & 2.64 & 6.49 & 1.07 & 1.65 & 28.80 & 1.78 & 3.00 & 78.94 & 164.79 \\
\hline $\begin{array}{l}\text { New } \\
\text { Zealand }\end{array}$ & 65.90 & 41.58 & 1.96 & 4.49 & 1.16 & 1.24 & 26.67 & 1.87 & 4.00 & 78.60 & 126.41 \\
\hline Norway & 66.98 & 36.12 & 2.03 & 5.22 & 1.68 & 1.16 & 36.63 & 1.91 & 2.00 & 93.28 & 70.84 \\
\hline Portugal & 51.35 & 34.27 & 1.55 & 5.46 & 1.13 & 0.70 & 53.12 & 1.11 & 1.00 & 85.00 & 142.23 \\
\hline Singapore & 34.14 & 32.30 & 1.49 & 4.42 & 1.41 & 2.74 & 29.99 & 1.65 & 3.00 & 92.28 & 96.77 \\
\hline Spain & 53.13 & 34.74 & 2.48 & 6.17 & 0.87 & 2.16 & 33.24 & 1.20 & 2.00 & 66.48 & 146.62 \\
\hline Sweden & 58.89 & 21.52 & 2.53 & 4.88 & 1.31 & 1.46 & 22.90 & 1.88 & 1.00 & 95.40 & 88.22 \\
\hline Switzerland & 60.02 & 32.02 & 2.21 & 6.04 & 1.04 & 2.78 & 24.75 & 1.88 & 1.00 & 84.63 & 160.68 \\
\hline Taiwan & 33.06 & 33.36 & 1.56 & 4.76 & 1.36 & 1.84 & 29.12 & 0.89 & 2.00 & 28.92 & 70.61 \\
\hline UK & 58.27 & 29.42 & 2.40 & 5.55 & 1.22 & 2.78 & 23.95 & 1.72 & 4.00 & 52.13 & 159.64 \\
\hline US & 73.10 & 30.10 & 2.69 & 6.06 & 1.22 & 2.36 & 25.40 & 1.61 & 1.00 & 30.33 & 51.78 \\
\hline Mean & 49.42 & 31.03 & 1.90 & 5.43 & 1.31 & 2.08 & 30.71 & 1.44 & 1.89 & 53.88 & 104.31 \\
\hline Median & 51.35 & 27.50 & 1.31 & 5.44 & 0.48 & 0.39 & 25.99 & 1.54 & 1.00 & 46.51 & 104.56 \\
\hline Std. Dev. & 34.34 & 22.16 & 2.07 & 2.14 & 2.82 & 10.18 & 23.76 & 0.36 & 1.18 & 20.35 & 37.41 \\
\hline First quart. & 16.95 & 13.42 & 0.76 & 4.16 & 0.20 & 0.15 & 10.43 & 1.29 & 1.11 & 36.73 & 85.48 \\
\hline Third quart. & 80.53 & 44.13 & 2.28 & 6.77 & 1.18 & 0.96 & 47.09 & 1.72 & 3.00 & 67.97 & 116.45 \\
\hline PANEL C: DE & JELOPING CO & NTRIES & & & & & & & & & \\
\hline$\overline{\text { Brazil }}$ & 51.38 & 36.86 & 1.65 & 5.74 & 1.16 & 1.87 & 39.99 & -0.26 & 1.00 & 51.48 & 36.80 \\
\hline Chile & 57.30 & 47.74 & 1.64 & 5.29 & 0.96 & 1.65 & 28.7 & 1.24 & 2.00 & 54.93 & 60.10 \\
\hline India & 53.87 & 38.52 & 1.79 & 4.17 & 1.01 & 2.48 & 42.96 & 0.02 & 2.00 & 31.43 & 41.95 \\
\hline Indonesia & 42.20 & 41.31 & 1.73 & 4.46 & 1.26 & 2.34 & 41.64 & -0.73 & 2.07 & 49.60 & 25.67 \\
\hline Malaysia & 33.28 & 38.80 & 1.21 & 3.96 & 1.30 & 2.78 & 34.38 & 0.49 & 3.00 & 49.75 & 99.83 \\
\hline Mexico & 63.71 & 47.13 & 1.58 & 6.28 & 1.02 & 1.70 & 36.38 & -0.48 & 0.00 & 60.93 & 16.88 \\
\hline Pakistan & 34.71 & 49.91 & 1.43 & 3.88 & 1.13 & 2.90 & 49.15 & -0.85 & 1.00 & 46.58 & 23.34 \\
\hline Peru & 41.66 & 49.61 & 1.61 & 4.57 & 1.07 & 3.14 & 32.10 & -0.67 & 0.00 & 74.39 & 21.62 \\
\hline Philippines & 41.34 & 40.53 & 1.47 & 5.15 & 1.47 & 1.46 & 37.23 & -0.49 & 1.00 & 47.10 & 30.22 \\
\hline South Africa & 44.69 & 31.04 & 2.16 & 5.27 & 1.07 & 4.59 & 23.94 & 0.10 & 3.00 & 77.79 & 70.90 \\
\hline South Korea & 32.92 & 35.01 & 1.19 & 5.09 & 1.39 & 1.86 & 40.59 & 0.90 & 3.00 & 58.69 & 92.23 \\
\hline Thailand & 32.84 & 41.12 & 1.46 & 4.29 & 1.19 & 3.57 & 36.9 & 0.02 & 2.10 & 48.42 & 93.49 \\
\hline Turkey & 33.10 & 35.80 & 1.90 & 4.92 & 1.35 & 4.82 & 28.44 & 0.03 & 2.00 & 55.46 & 26.85 \\
\hline Mean & 41.72 & 38.57 & 1.52 & 4.59 & 0.20 & 2.57 & 38.57 & 0.22 & 2.26 & 48.21 & 64.55 \\
\hline Median & 40.51 & 37.59 & 0.96 & 4.50 & 0.47 & 0.38 & 35.28 & 0.10 & 2.00 & 46.85 & 63.55 \\
\hline Std. Dev. & 32.54 & 21.33 & 1.86 & 1.85 & 2.64 & 11.44 & 27.09 & 0.55 & 0.77 & 16.18 & 30.89 \\
\hline First quart. & 9.42 & 22.08 & 0.54 & 3.41 & 19.69 & 0.17 & 14.75 & -0.08 & 2.00 & 35.44 & 41.11 \\
\hline Third quart. & 69.09 & 53.70 & 1.80 & 5.69 & 1.05 & 0.94 & 60.09 & 0.65 & 3.00 & 53.68 & 96.57 \\
\hline
\end{tabular}




\section{Table 2. Correlations}



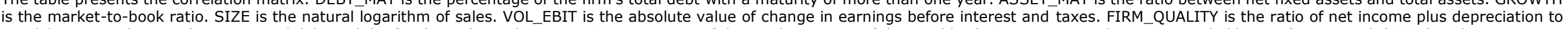

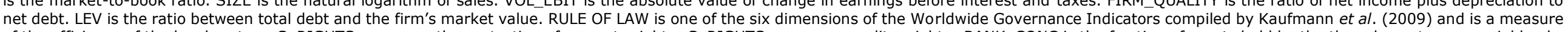

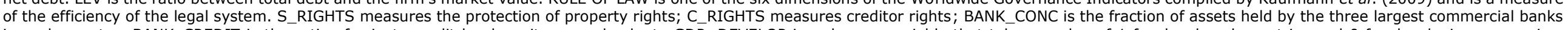

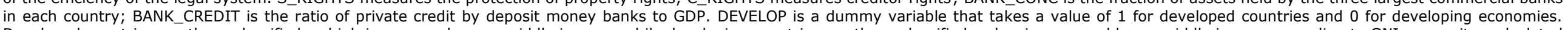

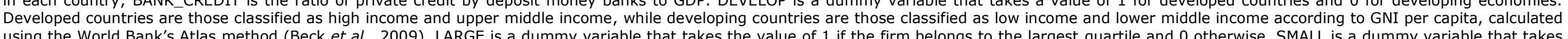
the value of 1 if the firm belongs to the smallest quartile and 0 otherwise. $* * *, * *$, and $*$ represent significance at the $1 \%, 5 \%$ and $10 \%$ levels, respectively.

\begin{tabular}{|c|c|c|c|c|c|c|c|c|c|c|c|c|c|}
\hline & DEBT_MAT & ASSET_MAT & GROWTH & SIZE & FIRM_QUALITY & VOL_EBIT & LEV & RULE_OF_LAW & C_RIGHTS & BANK_CONC & BANK_CREDIT & DEVELOP & LARGE \\
\hline ASSET_MAT & $0.178^{* * *}$ & & & & & & & & & & & & \\
\hline GROWTH & $0.099 * * *$ & $-0.103 * * *$ & & & & & & & & & & & \\
\hline SIZE & $0.222 * * *$ & $-0.011 * * *$ & $0.067 * * *$ & & & & & & & & & & \\
\hline FIRM_QUALITY & $-0.115^{* * *}$ & $-0.067 * * *$ & $0.069 * * *$ & $0.018^{* * *}$ & & & & & & & & & \\
\hline VOL_EBIT & $-0.028^{* * *}$ & -0.004 & $-0.022 * * *$ & $-0.101 * * *$ & $-0.037 * * *$ & & & & & & & & \\
\hline LEV & $0.071 * * *$ & $0.219 * * *$ & $-0.363^{* * *}$ & $0.041 * * *$ & $-0.240 * * *$ & $0.067 * * *$ & & & & & & & \\
\hline RULE_OF_LAW & $0.137 * * *$ & $-0.148^{* * *}$ & $0.099 * * *$ & $0.164 * * *$ & $-0.018 * * *$ & $0.024 * * *$ & $-0.170 * * *$ & & & & & & \\
\hline C_RIGTHS & $-0.092 * * *$ & $-0.016 * * *$ & $-0.021 * * *$ & $-0.132 * * *$ & $0.006^{* *}$ & $0.011^{* * *}$ & $-0.020 * * *$ & $0.068^{* * *}$ & & & & & \\
\hline BANK_CONC & $-0.033 * * *$ & $-0.056 * * *$ & $0.016^{* * *}$ & $-0.075 * * *$ & $-0.006 * *$ & $0.021 * * *$ & $-0.062 * * *$ & $0.282 * * *$ & $0.464 * * *$ & & & & \\
\hline BANK_CREDIT & $-0.078 * * *$ & $-0.131 * * *$ & $-0.037 * * *$ & $0.059 * * *$ & $-0.015^{* * *}$ & $0.028 * * *$ & $-0.059 * * *$ & $0.563 * * *$ & $0.283 * * *$ & $0.385^{* * *}$ & & & \\
\hline DEVELOP & $0.103^{* * *}$ & $-0.154 * * *$ & $0.086^{* * *}$ & $0.183^{* * *}$ & $-0.021^{* * *}$ & $0.018^{* * *}$ & $-0.143^{* * *}$ & $0.796 * * *$ & $-0.154 * * *$ & $0.463^{* * *}$ & $0.131 * * *$ & & \\
\hline LARGE & $0.271 * * *$ & $0.055^{* * *}$ & $0.082 * * *$ & $0.684 * * *$ & $-0.029 * * *$ & $-0.060 * * *$ & $0.035^{* * *}$ & $0.127 * * *$ & $-0.089 * * *$ & $0.050 * * *$ & $-0.023 * * *$ & $0.131^{* * *}$ & \\
\hline SMALL & $-0.194 * * *$ & $-0.069 * * *$ & $0.005^{* *}$ & $-0.640 * * *$ & 0.000 & $0.064 * * *$ & $-0.078^{* * *}$ & $-0.120 * * *$ & $0.086 * * *$ & $-0.053^{* * *}$ & $0.065 * * *$ & $-0.144 * * *$ & $-0.333 * * *$ \\
\hline
\end{tabular}




\section{Table 3. Determinants of firm debt maturity}

Regressions are estimated using panel data. Columns (1) and (2) show the results for the total sample, while columns ( 3 ) and (4) and (5) and (6) show the results for the samples of developing and developed countries, respectively. Developed countries are those classified as high income and upper middle income, while developing countries are those classified as low income and lower middle income according to GNI per capita, calculated using the World Bank's Atlas method (Beck et al., 2009). The dependent variable (DEBT MAT) is the percentage of the firm's total debt with a maturity of more than one year. ASSET MAT is the ratio between net fixed assets and total assets. GROWTH is the market-to-book ratio. SIZE is the natural logarithm of sales. VOL_EBIT is the absolute value of change in earnings before interest and taxes. FIRM_QUALITY is the ratio of net income plus depreciation to net debt. LEV is the ratio between total debt and the firm's market value. RULE_OF_LAW is one of the six dimensions of the WGI and is a measure of the efficiency of the legal system. C_RIGHTS measures creditor rights. BANK_CONC is the fraction of assets held by the three largest commercial banks in each country. BANK_CREDIT is the ratio of private credit by deposit money banks to GDP. T-statistics are in parentheses. $* * *, * *$, and $*$ represent significance at the $1 \%, 5 \%$, and $10 \%$ levels, respectively.

\begin{tabular}{|c|c|c|c|c|c|c|}
\hline & (1) & (2) & (3) & (4) & (5) & (6) \\
\hline Intercept & $\begin{array}{c}0.4493 * * * \\
(52.51)\end{array}$ & $\begin{array}{c}0.3754 * * * \\
(21.28)\end{array}$ & $\begin{array}{c}0.4848^{* * *} \\
(33.00)\end{array}$ & $\begin{array}{c}0.5495 * * * \\
(14.30)\end{array}$ & $\begin{array}{c}0.4330 * * * \\
(41.12)\end{array}$ & $\begin{array}{c}0.4201 * * * \\
(15.57)\end{array}$ \\
\hline ASSET_MAT & $\begin{array}{c}0.0576 * * * \\
(6.61)\end{array}$ & $\begin{array}{c}0.0538 * * * \\
(5.72)\end{array}$ & $\begin{array}{c}0.0858 * * * \\
(6.10)\end{array}$ & $\begin{array}{c}0.0854 * * * \\
(5.73)\end{array}$ & $\begin{array}{c}0.0390 * * * \\
(3.52)\end{array}$ & $\begin{array}{c}0.0294 * * \\
(2.42)\end{array}$ \\
\hline GROWTH & $\begin{array}{c}0.0035 * * * \\
(6.85)\end{array}$ & $\begin{array}{c}0.0034 * * * \\
(6.22)\end{array}$ & $\begin{array}{c}0.0054 * * * \\
(5.26)\end{array}$ & $\begin{array}{c}0.0053^{* * *} \\
(4.99)\end{array}$ & $\begin{array}{c}0.0031 * * * \\
(5.27)\end{array}$ & $\begin{array}{c}0.0029 * * * \\
(4.65)\end{array}$ \\
\hline SIZE & $\begin{array}{c}0.0032^{* *} \\
(2.11)\end{array}$ & $\begin{array}{c}0.0030^{*} \\
(1.82)\end{array}$ & $\begin{array}{c}-0.0119^{* * * *} \\
(-4.28)\end{array}$ & $\begin{array}{c}-0.0103^{* * *} \\
(-3.43)\end{array}$ & $\begin{array}{c}0.0100 * * * \\
(5.55)\end{array}$ & $\begin{array}{c}0.0097 * * * \\
(4.93)\end{array}$ \\
\hline VOL_EBIT & $\begin{array}{l}-0.002 \\
(-0.85)\end{array}$ & $\begin{array}{c}-0.0001 \\
(-0.32)\end{array}$ & $\begin{array}{c}-0.0003 \\
(-0.67)\end{array}$ & $\begin{array}{c}-0.0002 \\
(-0.50)\end{array}$ & $\begin{array}{c}-0.0002 \\
(-0.74)\end{array}$ & $\begin{array}{c}-0.0001 \\
(-0.19)\end{array}$ \\
\hline FIRM_QUALITY & $\begin{array}{c}-0.0009 * * * \\
(-9.76)\end{array}$ & $\begin{array}{c}-0.0008 * * * \\
(-8.59)\end{array}$ & $\begin{array}{c}-0.0008 * * * \\
(-5.02)\end{array}$ & $\begin{array}{c}-0.0007 * * * \\
(-3.82)\end{array}$ & $\begin{array}{c}-0.0010 * * * \\
(-8.45)\end{array}$ & $\begin{array}{c}-0.0009 * * * \\
(-7.81)\end{array}$ \\
\hline LEV & $\begin{array}{c}0.0482 * * * \\
(9.32)\end{array}$ & $\begin{array}{c}0.0629 * * * \\
(11.21)\end{array}$ & $\begin{array}{c}0.0396 * * * \\
(4.44)\end{array}$ & $\begin{array}{c}0.0529 * * * \\
(5.57)\end{array}$ & $\begin{array}{c}0.0507 * * * \\
(7.95)\end{array}$ & $\begin{array}{c}0.0668^{* * *} \\
(9.55)\end{array}$ \\
\hline RULE_OF_LAW & - & $\begin{array}{c}0.0466 * * * \\
(4.28)\end{array}$ & - & $\begin{array}{c}0.1066 * * * \\
(6.61)\end{array}$ & - & $\begin{array}{l}0.0247 \\
(1.57)\end{array}$ \\
\hline C_RIGHTS & - & $\begin{array}{c}0.0092 * * * \\
(3.16)\end{array}$ & - & $\begin{array}{c}-0.0474 * * * \\
(-2.92)\end{array}$ & - & $\begin{array}{c}0.0153^{* * * *} \\
(5.10)\end{array}$ \\
\hline BANK_CONC & - & $\begin{array}{c}0.0665 * * * \\
(5.30)\end{array}$ & - & $\begin{array}{c}0.1279 * * * \\
(6.74)\end{array}$ & - & $\begin{array}{c}-0.0342 * \\
(-1.80)\end{array}$ \\
\hline BANK_CREDIT & - & $\begin{array}{c}-0.0350 * * * \\
(-4.39)\end{array}$ & - & $\begin{array}{c}-0.1365^{* * * *} \\
(-5.30)\end{array}$ & - & $\begin{array}{c}-0.0283 * * * \\
(-3.29)\end{array}$ \\
\hline Hausman test & $1,437.30 * * *$ & $1,433.73 * * *$ & $657.59 * * *$ & $586.62 * * *$ & $911.29 * * *$ & $902.43 * * *$ \\
\hline $\mathrm{F}$ test & $48.23 * * *$ & $36.74 * * *$ & $35.22 * * *$ & $30.75 * * *$ & $29.43 * * *$ & $23.06 * * *$ \\
\hline \# observations & 135,621 & 118,434 & 39,146 & 35,522 & 96,475 & 82,912 \\
\hline \# firms & 27,881 & 25,221 & 8,349 & 8,194 & 19,532 & 17,027 \\
\hline
\end{tabular}




\section{Table 4. Country-level determinants of debt maturity according to firm size}

Regressions are estimated using panel data. Columns (1) and (2) show the results for developing countries and columns (3) and (4) for developed countries. Developed countries are those classified as high income and upper middle income, while developing countries are those classified as low income and lower middle income according to GNI per capita, calculated using the World Bank's Atlas method (Beck et al., 2009). The dependent variable (DEBT_MAT) is the percentage of the firm's total debt with a maturity of more than one year. ASSET MAT is the ratio between net fixed assets and total assets. GROWTH is the growth rate of the GDP. SIZE is the natural logarithm of sales. VOL_EBIT is the absolute value of change in earnings before interest and taxes. FIRM_QUALITY is the ratio of net income plus depreciation to net debt. LEV is the ratio between total debt and the firm's market value. DCRISIS is a dummy variables that takes the value of 1 for the years $2008,2009,2010,2011$, and 2012 and zero otherwise. RULE OF LAW is one of the six dimensions of the WGI and is a measure of the efficiency of the legal system. S_RIGHTS measures the protection of property rights. C_RIGHTS measures creditor rights. BANK_CREDIT is the ratio of private credit by deposit money banks to GDP. BANK_CONC is the fraction of assets held by the three largest commercial banks in each country. LARGE is a dummy variable that takes the value of 1 if the firm belongs to the largest quartile and 0 otherwise. SMALL is a dummy variable that takes the value of 1 if the firm belongs to the smallest quartile and 0 otherwise. T-statistics are in parentheses. $* * *, * *$, and $*$ represent significance at the $1 \%$, $5 \%$, and $10 \%$ levels, respectively.

\begin{tabular}{|c|c|c|c|c|}
\hline & (1) & (2) & (3) & (4) \\
\hline Intercept & $\begin{array}{c}0.5598 * * * \\
(14.48)\end{array}$ & $\begin{array}{c}0.5607 * * * \\
(14.46)\end{array}$ & $\begin{array}{c}0.4295^{* * *} \\
(15.84)\end{array}$ & $\begin{array}{c}0.4445 * * * \\
(16.39)\end{array}$ \\
\hline ASSET_MAT & $\begin{array}{c}0.0858 * * * \\
(5.76)\end{array}$ & $\begin{array}{c}0.0850 * * * \\
(5.71)\end{array}$ & $\begin{array}{c}0.0301 * * \\
(2.48)\end{array}$ & $\begin{array}{c}0.0311 * * * \\
(2.57)\end{array}$ \\
\hline GROWTH & $\begin{array}{c}0.0052 * * * \\
(4.92)\end{array}$ & $\begin{array}{c}0.0052 * * * \\
(4.89)\end{array}$ & $\begin{array}{l}0.0029 * * * \\
(4.59)\end{array}$ & $\begin{array}{c}0.0028 * * * \\
(4.42)\end{array}$ \\
\hline SIZE & $\begin{array}{c}-0.0117 * * * \\
(-3.86)\end{array}$ & $\begin{array}{c}-0.0128 * * * \\
(-4.25)\end{array}$ & $\begin{array}{c}0.0079 * * * \\
(3.99)\end{array}$ & $\begin{array}{c}0.0062 * * * \\
(3.13)\end{array}$ \\
\hline VOL_EBIT & $\begin{array}{l}-0.0002 \\
(-0.51)\end{array}$ & $\begin{array}{c}-0.0002 \\
(-0.47)\end{array}$ & $\begin{array}{l}-0.0001 \\
(-0.20)\end{array}$ & $\begin{array}{l}-0.0001 \\
(-0.20)\end{array}$ \\
\hline FIRM_QUALITY & $\begin{array}{c}-0.0007 * * * \\
(-3.77)\end{array}$ & $\begin{array}{c}-0.0007 * * * \\
(-3.90)\end{array}$ & $\begin{array}{c}-0.0009 * * * \\
(-7.83)\end{array}$ & $\begin{array}{c}-0.0009 * * * \\
(-7.75)\end{array}$ \\
\hline LEV & $\begin{array}{c}0.0520 * * * \\
(5.48)\end{array}$ & $\begin{array}{c}0.0530 * * * \\
(5.59)\end{array}$ & $\begin{array}{c}0.0670 * * * \\
(9.60)\end{array}$ & $\begin{array}{c}0.0694 * * * \\
(9.94)\end{array}$ \\
\hline RULE_OF_LAW & $\begin{array}{l}0.1062^{* * * *} \\
(6.20)\end{array}$ & $\begin{array}{c}0.0975 * * * \\
(5.90)\end{array}$ & $\begin{array}{l}0.0245 \\
(1.54)\end{array}$ & $\begin{array}{c}0.0278^{*} \\
(1.75)\end{array}$ \\
\hline C_RIGHTS & $\begin{array}{c}-0.0438 * * * \\
(-2.67)\end{array}$ & $\begin{array}{c}-0.0403^{* *} \\
(-2.43)\end{array}$ & $\begin{array}{c}0.0193^{* * * *} \\
(5.45)\end{array}$ & $\begin{array}{c}0.0149 * * * \\
(4.95)\end{array}$ \\
\hline BANK_CONC & $\begin{array}{c}0.1288 * * * \\
(6.21)\end{array}$ & $\begin{array}{c}0.1200 * * * \\
(6.16)\end{array}$ & $\begin{array}{c}-0.0393^{*} \\
(-1.95)\end{array}$ & $\begin{array}{c}-0.0365^{*} \\
(-1.89)\end{array}$ \\
\hline BANK_CREDIT & $\begin{array}{c}-0.1588^{* * *} \\
(-5.92)\end{array}$ & $\begin{array}{c}-0.1198 * * * \\
(-4.47)\end{array}$ & $\begin{array}{c}-0.0403 * * * \\
(-4.35)\end{array}$ & $\begin{array}{c}-0.0269 * * * \\
(-2.99)\end{array}$ \\
\hline LARGE*RULE_OF_LAW & $\begin{array}{c}-0.0102 \\
(-0.53)\end{array}$ & - & $\begin{array}{l}0.0003 \\
(0.04)\end{array}$ & - \\
\hline LARGE*C_RIGHTS & $\begin{array}{l}-0.0114 \\
(-1.04)\end{array}$ & - & $\begin{array}{c}-0.0079 * * \\
(-2.04)\end{array}$ & - \\
\hline LARGE*BANK_CONC & $\begin{array}{c}-0.0092 \\
(-0.31)\end{array}$ & - & $\begin{array}{l}0.0139 \\
(0.60)\end{array}$ & - \\
\hline LARGE*BANK_CREDIT & $\begin{array}{c}0.0948 * * * \\
(2.66)\end{array}$ & - & $\begin{array}{c}0.0341 * * * \\
(3.05)\end{array}$ & - \\
\hline SMALL*RULE_OF_LAW & - & $\begin{array}{c}0.0381 * * \\
(2.41)\end{array}$ & - & $\begin{array}{l}0.0039 \\
(0.38)\end{array}$ \\
\hline SMALL*C_RIGHTS & - & $\begin{array}{l}-0.0149 \\
(-1.41)\end{array}$ & - & $\begin{array}{c}-0.0170 * * * \\
(-3.52)\end{array}$ \\
\hline SMALL*BANK_CONC & - & $\begin{array}{l}0.0515 \\
(1.52)\end{array}$ & - & $\begin{array}{l}0.0083 \\
(0.36)\end{array}$ \\
\hline SMALL*BANK_CREDIT & - & $\begin{array}{c}-0.0674 * * \\
(-2.24)\end{array}$ & - & $\begin{array}{c}-0.0287 * * \\
(-2.24)\end{array}$ \\
\hline Hausman test & $728.33 * * *$ & $607.01 * * *$ & $1,089.03 * * *$ & $981.28 * * *$ \\
\hline$F$ test & $24.17 * * *$ & $26.90 * * *$ & $19.88^{* * *}$ & $27.37 * * *$ \\
\hline \# observations & 35,522 & 35,522 & 82,912 & 82,912 \\
\hline \# firms & 8,194 & 8,194 & 17,027 & 17,027 \\
\hline
\end{tabular}




\section{Table 5. Determinants of firm debt maturity}

Regressions are estimated using panel data. Column (1) shows the results for the total sample, while columns (2) and (3) show the results for the samples of developing and developed countries, respectively. Developed countries are those classified as high income and upper middle income, while developing countries are those classified as low income and lower middle income according to GNI per capita, calculated using the World Bank's Atlas method (Beck et al., 2009). The dependent variable (DEBT MAT) is the percentage of the firm's total debt with a maturity of more than one year. ASSET MAT is the ratio between net fixed assets and total assets. GROWTH is the market-to-book ratio. SIZE is the natural logarithm of sales. VOL_EBIT is the absolute value of change in earnings before interest and taxes. FIRM_QUALITY is the ratio of net income plus depreciation to net debt. LEV is the ratio between total debt and the firm's market value. RULE_OF_LAW is one of the six dimensions of the WGI and is a measure of the efficiency of the legal system. C RIGHTS measures creditor rights. BANK CONC is the fraction of assets held by the three largest commercial banks in each country. BANK_CREDIT is the ratio of private credit by deposit money banks to GDP. DCRISIS is a dummy variable that takes the value of 1 for the years 2008 to 2012 and zero otherwise. T-statistics are in parentheses. $* * *, * *$, and $*$ represent significance at the $1 \%, 5 \%$, and $10 \%$ levels, respectively.

\begin{tabular}{|c|c|c|c|}
\hline & $(1)$ & (2) & (3) \\
\hline Intercept & $\begin{array}{c}0.3865^{* * *} \\
(20.91)\end{array}$ & $\begin{array}{c}0.5508^{* * *} \\
(13.59)\end{array}$ & $\begin{array}{c}0.4262 * * * \\
(15.27)\end{array}$ \\
\hline ASSET_MAT & $\begin{array}{c}0.0554 * * * \\
(5.87)\end{array}$ & $\begin{array}{c}0.0936 * * * \\
(6.26)\end{array}$ & $\begin{array}{c}0.0322 * * * \\
(2.65)\end{array}$ \\
\hline GROWTH & $\begin{array}{c}0.0033^{*} * * \\
(6.04)\end{array}$ & $\begin{array}{c}0.0050 * * * \\
(4.70)\end{array}$ & $\begin{array}{c}0.0028 * * * \\
(4.42)\end{array}$ \\
\hline SIZE & $\begin{array}{c}0.0033^{* *} \\
(1.97)\end{array}$ & $\begin{array}{c}-0.0106 * * * \\
(-3.48)\end{array}$ & $\begin{array}{c}0.0093 * * * \\
(4.71)\end{array}$ \\
\hline VOL_EBIT & $\begin{array}{c}-0.0001 \\
(-0.31)\end{array}$ & $\begin{array}{c}-0.0003 \\
(-0.56)\end{array}$ & $\begin{array}{c}-0.0001 \\
(-0.21)\end{array}$ \\
\hline FIRM_QUALITY & $\begin{array}{c}-0.0008 * * * \\
(-8.53)\end{array}$ & $\begin{array}{c}-0.0006 * * * \\
(-3.69)\end{array}$ & $\begin{array}{c}-0.0009 * * * \\
(-7.71)\end{array}$ \\
\hline LEV & $\begin{array}{c}0.0645^{* * *} \\
(11.49)\end{array}$ & $\begin{array}{c}0.0526 * * * \\
(5.55)\end{array}$ & $\begin{array}{c}0.0714 * * * \\
(10.18)\end{array}$ \\
\hline RULE_OF_LAW & $\begin{array}{c}0.0345^{* * *} \\
(3.11)\end{array}$ & $\begin{array}{c}0.0780 * * * \\
(3.95)\end{array}$ & $\begin{array}{l}0.0031 \\
(0.19)\end{array}$ \\
\hline C_RIGHTS & $\begin{array}{c}0.0113^{* * * *} \\
(3.86)\end{array}$ & $\begin{array}{c}-0.0447 * * * \\
(-2.73)\end{array}$ & $\begin{array}{c}0.0172 * * * \\
(5.69)\end{array}$ \\
\hline BANK_CONC & $\begin{array}{c}0.0570 * * * \\
(4.41)\end{array}$ & $\begin{array}{c}0.1738 * * * \\
(7.02)\end{array}$ & $\begin{array}{c}-0.0144 \\
(-0.73)\end{array}$ \\
\hline BANK_CREDIT & $\begin{array}{c}-0.0378 * * * \\
(-4.04)\end{array}$ & $\begin{array}{c}-0.1642 * * * \\
(-6.04)\end{array}$ & $\begin{array}{c}-0.0191^{*} \\
(-1.82)\end{array}$ \\
\hline DCRISIS & $\begin{array}{c}-0.0462 * * * \\
(-6.45)\end{array}$ & $\begin{array}{l}-0.0254 \\
(-1.15)\end{array}$ & $\begin{array}{c}-0.0645 * * * \\
(-5.49)\end{array}$ \\
\hline DCRISIS*RULE_OF_LAW & $\begin{array}{c}0.0101 * * * \\
(2.80)\end{array}$ & $\begin{array}{l}0.0255 \\
(1.61)\end{array}$ & $\begin{array}{c}0.0342^{* * *} * \\
(4.86)\end{array}$ \\
\hline DCRISIS*C_RIGHTS & $\begin{array}{l}0.0026 \\
(1.39)\end{array}$ & $\begin{array}{c}-0.0059 \\
(-0.72)\end{array}$ & $\begin{array}{l}0.0029 \\
(1.26)\end{array}$ \\
\hline DCRISIS*BANK_CONC & $\begin{array}{c}0.0592 * * * \\
(4.63)\end{array}$ & $\begin{array}{c}0.0869 * * * \\
(2.71)\end{array}$ & $\begin{array}{c}0.0291^{* *} \\
(2.01)\end{array}$ \\
\hline DCRISIS*BANK_CREDIT & $\begin{array}{c}-0.0090 \\
(-1.31)\end{array}$ & $\begin{array}{c}0.0179 \\
(0.91)\end{array}$ & $\begin{array}{c}-0.0140 * \\
(-1.83)\end{array}$ \\
\hline Hausman test & $1,936.57^{* * *}$ & $659.21 * * *$ & $1,358.38$ \\
\hline $\mathrm{F}$ test & $29.56 * * *$ & $23.83 * * *$ & $19.60 * * *$ \\
\hline \# observations & 118,434 & 35,522 & 82,912 \\
\hline \# firms & 25,221 & 8,194 & 17,027 \\
\hline
\end{tabular}

